\title{
Development in Lexicography: From Polyfunctional to Monofunctional Accounting Dictionaries
}

\author{
Sandro Nielsen, Centre for Lexicography, Aarhus University, \\ Aarhus, Denmark and International Centre for Lexicography, \\ Universidad de Valladolid, Valladolid, Spain \\ (sn@asb.dk) \\ and \\ Pedro A. Fuertes-Olivera, International Centre for Lexicography, \\ Universidad de Valladolid, Valladolid, Spain \\ (pedro@emp.uva.es)
}

\begin{abstract}
This article describes the theoretical foundation of the accounting dictionaries as well as its practical results. Furthermore, the implementation of the project shows how the constant interaction of lexicographical theory with practical dictionary work over a period of 10 years has led to lexicographical development and adaptation resulting in ongoing adjustments to the dictionaries and their theoretical foundation. This is exemplified by studying the transition from polyfunctional to monofunctional dictionaries in an attempt to provide help in several types of usage situations, typically in communicative situations, e.g. when reading, writing or translating English, Danish or Spanish accounting texts, or cognitive situations, i.e. when users want to know more about accounting matters or accounting language. The article also indicates that the creation of this project connects e-lexicography with the knowledge-based economy. Lexicographers work in the cloud being physically thousands of kilometres away; they work with experts in accounting, databases and the Internet with the aim of constructing and updating a high-quality tool with relatively low information costs for users. Finally, this article shows that the future of lexicography rests on designing, constructing, and updating information tools that take into consideration not only the true nature of lexicography but also the possibilities of the Internet and its technologies, as advocates of the Function Theory of Lexicography do on a regular basis.
\end{abstract}

Keywords: SPECIALIZED LEXICOGRAPHY, FUNCTION THEORY, POLYFUNCTIONAL DICTIONARY, MONOFUNCTIONAL DICTIONARY, ACCOUNTING DICTIONARIES, INFORMATION TOOLS, LEXICOGRAPHICAL INFORMATION COSTS, ONLINE DICTIONARY, ELECTRONIC LEXICOGRAPHY, INTERNET, MEANING, WRITING, TRANSLATION, KNOWLEDGE, DANISH, ENGLISH, SPANISH

Opsomming: Ontwikkeling in die leksikografie: Van polifunksionele tot monofunksionele rekenkundige woordeboeke. Hierdie artikel beskryf sowel die teoretiese grondslag van die rekenkundige woordeboeke as die praktiese resultate daarvan. Verder 
het die implementering van die projek getoon hoe die voortdurende wisselwerking van leksikografiese teorie met praktiese woordeboekwerk oor 'n tydperk van 10 jaar gelei het tot leksikografiese ontwikkeling en wysiging wat voortdurende aanpassings aan die woordeboeke en hul teoretiese grondslag tot gevolg gehad het. Dit word geïllustreer deur te let op die oorgang van polifunksionele na monofunksionele woordeboeke in 'n poging om hulp te verleen in verskeie soorte gebruiksituasies, gewoonlik in kommunikatiewe situasies, bv. wanneer Engelse, Deense of Spaanse rekenkundige tekste gelees, geskryf of vertaal word, of in kognitiewe situasies, d.i. wanneer gebruikers meer wil weet oor rekenkundige aangeleenthede of rekenkundige taal. Die artikel toon ook dat die skepping van hierdie projek e-leksikografie met die kennis-gebaseerde ekonomie verbind. Leksikograwe werk in die wolk deur fisies duisende kilometers van mekaar te wees; hulle werk met kundiges in die rekeningkunde, databasisse en die Internet met die doel om 'n hoëdrukgehaltewerktuig te bou en aan te pas met 'n relatief lae inligtingskoste vir gebruikers. Ten slotte toon hierdie artikel dat die toekoms van die leksikografie lê in die ontwerp, bou en aanpassing van inligtingswerktuie wat nie net die ware aard van die leksikografie in aanmerking neem nie, maar ook die moontlikhede van die Internet en sy tegnologieë, soos die voorstanders van die Funksieteorie van die Leksikografie op 'n gereelde basis doen.

Sleutelwoorde: GESPESIALISEERDE LEKSIKOGRAFIE, FUNKSIETEORIE, POLIFUNKSIONELE WOORDEBOEK, MONOFUNKSIONELE WOORDEBOEK, REKENINGKUNDIGE WOORDEBOEKE, INLIGTINGSWERKTUIE, LEKSIKOGRAFIESE INLIGTINGSKOSTE, AANLYN WOORDEBOEK, ELEKTRONIESE LEKSIKOGRAFIE, INTERNET, BETEKENIS, SKRYF, VERTALING, KENNIS, DEENS, ENGELS, SPAANS

\section{Introduction}

Specialized dictionaries, i.e. dictionaries that cover specific domains and/or their languages, have been around for many years. They were primarily seen as practical tools of the trade, and little thought was given to a theoretical framework within which these dictionaries could be designed and produced. During the 19th and most of the 20th centuries, lexicography was considered a practical vocation based on linguistics and linguistic theories, but in the last half of the 20th century lexicographers began to study specialized dictionaries in order to analyze and describe these products as repositories of lexicon and knowledge as proposed in e.g. Frawley (1988) and Wiegand (1988). This theoretical framework applied to printed monolingual dictionaries and used primarily linguistic and text-linguistic principles. Around that time, lexicographers extended their interest to bilingual dictionaries by focusing mainly on equivalence and equivalents. Furthermore, during the 1990s, researchers introduced a new approach to lexicography and regarded general and specialized dictionaries as complex lexicographical tools that contain more than linguistic concepts and terms as described in e.g. Nielsen (1994), Schaeder and Bergenholtz (1994), Bergenholtz and Tarp (1995), and Bergenholtz (1996).

Lexicography, and by implication specialized lexicography, is thus a dynamic field that needs to keep up with and adapt to the development of 
modern society, in particular the change from paper-based data to electronic data and the use of electronic information platforms, see e.g. Fuertes-Olivera (2013), Fuertes-Olivera and Tarp (2014), and Nielsen (2013). Bergenholtz (1996), Tarp (2000, 2001), Nielsen and Mourier (2005, 2007), Fuertes-Olivera (2009), Nielsen (2010), Fuertes-Olivera and Nielsen (2012), and Fuertes-Olivera and Tarp (2014) show that practical as well as theoretical lexicography cannot develop properly by focusing exclusively on documentation, description and analysis in a linguistic tradition but should turn its attention to the development of lexicographically relevant principles that can guide lexicographers in their quest for designing and producing dictionaries that help users solve specific types of problems in specific types of situations in the modern information society. Aspects of the recent development in lexicography will be described with particular reference to a dictionary project that involves a set of specialized online dictionaries within the field of accounting, collectively referred to below as the Accounting Dictionaries. The theoretical foundation of the dictionary project will be described as well as its practical results. Furthermore, the constant interaction of theory with practical dictionary work over a period of 10 years has led to lexicographical adaptation resulting in ongoing adjustments to the dictionaries and their theoretical foundation. This will be exemplified by studying the transition from polyfunctional to monofunctional dictionaries in an attempt to provide help that satisfies user needs.

\section{Origins of the project}

The Accounting Dictionaries, a set of 28 monolingual and bilingual dictionaries, are the result of a joint project involving lexicographers and subject-field specialists from a number of universities in Denmark and Spain. At present, the Danish participants come from the Centre for Lexicography affiliated with the Department of Business Communication, Aarhus University, and the Spanish participants are affiliated with the International Centre for Lexicography, University of Valladolid. In 2001, lexicographers at the Danish Centre started preparing the lexicographical basis for the compilation of a bilingual accounting dictionary covering the languages Danish and English. The planned dictionary was intended to be a practical tool designed to help Danish enterprises meet the increasing need to present their financial reporting in linguistically and terminologically correct English. From the start, the dictionary was designed as an electronic dictionary to be freely accessible on the Internet; see Nielsen (2002) for a detailed description of the theoretical foundation.

At the turn of the century, lexicography was slowly changing its focus though conventional wisdom was still oriented towards linguistic and text-linguistic approaches to dictionary making and research (see e.g. Schneider 1998, Lindemann 2000, and Landau 2001). The lexicographers felt that this focus on documentation, description and analysis based on a linguistic tradition was unsatisfactory; it did not provide the necessary help to establish a sound theo- 
retical foundation embracing the types of problems involved in making the planned dictionary. This resembled a situation described by Chesterton (2001: 141): "It isn't that they can't see the solution. It's that they can't see the problem." As a result, the lexicographers had to look for another approach.

The problem was not to make a bilingual dictionary that would be a repository of various types of data representing linguistic concepts and principles documenting the lexicon of accounting. The real challenge was to make an online bilingual accounting dictionary that provided help to specific types of users to solve specific types of problems when translating accounting texts from Danish into English or producing accounting texts directly in English. In this light, the modern theory of lexicographical functions presented in e.g. Bergenholtz (1996), Bergenholtz and Kaufmann (1997) and Tarp (2000) indicated new possibilities for planning and compiling such dictionaries.

Any project based on a theoretical foundation need to have a clear understanding of what a dictionary actually is. A dictionary has traditionally been described as a reference work that presents the vocabulary of a language, usually in alphabetical order, with explanations of meanings in the same language or with equivalents in another language (see e.g. Hartmann and James 2001: 41; and Van Sterkenburg 2003: 396). However, the new lexicographical approach adopted regards the dictionary as an information tool with three significant features. The overriding feature is that the dictionary has one or more functions, e.g. communicative functions such as providing help to understand, translate and write texts, and cognitive functions such as providing help to acquire knowledge in communication-free contexts. This feature concerns the dictionary's lexicographical potential as an aid in particular types of usage situation. Secondly, the dictionary contains lexicographical data that support its function(s). This second feature interacts with the first one, because the potential of the dictionary can only be realized through the data presented. Finally, the lexicographical structures marshal the data into the task of fulfilling the dictionary function(s). This is the feature that makes it possible to unite the lexicographical data and the function(s) to produce a whole and to operationalize the relation and interaction between data based on specific lexicographical principles (see e.g. Nielsen 2003: 111-112; and Nielsen 2009b: 215). The point is that the intention behind the dictionary is not found in either the first, the second or the third feature, but in the aggregate of significant features, i.e. the electronic (or printed) dictionary in its entirety.

The adoption of the functional theory of lexicography means that the goal was to develop a lexicographical tool that would provide help to solve specific types of problems encountered by specific types of users in the context of translation into or production of texts in English. The next challenge was to identify and select the lexicographical data types that would support the intended lexicographical functions. Few reported studies deal with specialized translation dictionaries, e.g. Duvå and Laursen (1994), Nielsen (1994: 12-32), Wang (2001: 75-137) and Muráth (2002: 43-79), and only the first study concerns the lexico- 
graphical needs of persons translating specialized texts into a foreign language. One drawback of the available user surveys is that the majority of informants are learners with limited experience and knowledge of translating specialized texts. Secondly, each set of findings relates to one particular text genre and therefore says nothing about translating specialized texts in general. Thirdly, the studies examine a limited number of subject fields so that they provide few new insights into the general activity of specialized translation. Fourthly, the number of informants in each study is so small that the results are not representative. Finally, the results reflect the subjective problems, needs, etc. recognized by the informants, whereas unrecognized needs go unnoticed. The findings therefore do not provide solid proof of actual usage situations or clear guidelines for designing specialized translation dictionaries (see Tarp 2009: 290-292 for a discussion of lexicographical user research).

In contrast to the above user studies, the functional theory allows lexicographers to work fast by consulting the research literature published in the field of translation studies. Several scholars have examined the elements of the translation process, and some of their findings are relevant for translating specialized texts and specialized lexicography. For instance, Nord (2005) demonstrates that the translation process contains several recursive steps that go beyond the level of terms and words, and Bell (2000: 211) focuses on translation units larger than words by identifying syntactic, semantic and pragmatic knowledge as necessary elements in translating texts. In particular, translators need syntactic knowledge about possible ways of combining words, and structuring word groups as well as restrictions in the foreign language in order to avoid linear dislocation. Here dictionaries can help by showing e.g. collocations and phrases that are relevant for the language of the domain. Semantic knowledge is relevant because translators need to know the exact meanings of domain-specific words and multi-word terms to properly understand differences in the structure of the domains in the two cultures involved, including hierarchical relationships such as superordination and homonymy. Clear definitions written in the appropriate language and style, synonyms and antonyms can help translators acquiring the necessary knowledge. Finally, pragmatic knowledge will tell translators how utterances are used in given contexts, i.e. how textual resources in the foreign language are conventionally used and what is textually appropriate or normal in communication within the field of accounting. Dictionaries can provide help through the presentation of collocations, phrases, example sentences and usage notes (See Sections 4 and 5 for a further discussion and examples).

In addition, some of the lexicographers in the project are experts in specialized translation and had, at the start of the project, more than 25 years' experience between them teaching specialized translation to students of English at undergraduate and postgraduate level; experience thus played a role in selecting the lexicographical data. In the field of epistemology, this type of experience is recognized as a source of knowledge and falls under the heading perception. It should be appreciated that the experience referred to is not the 
same as introspection:

Through perception, we acquire (primarily) justified beliefs and knowledge about the external world; without these, we would be unlikely to survive. Through introspection, we acquire (primarily) justified beliefs and knowledge only about the mental world; with only this, our knowledge and justification would be sadly limited to our own minds. (Audi 2003: 91)

Compared to the method of surveying dictionary users, the use of findings by translation scholars combined with the relevant experience of translation experts has a number of benefits. Overall, the findings represent types of general elements of the translation process, and translation scholars and university teachers of specialized translation are experts in translating texts and have considerable practical as well as theoretical experience of the entire translation process. This may result in the inclusion of data types in the dictionary that can help users solve general types of problems, such as proscriptive presentation of equivalents, translation of collocations and phrases, as well as usage notes. Furthermore, specialized translation dictionaries that take these findings into consideration will address general user needs and not be biased towards subjective needs. Finally, the use of existing research results and perception allows lexicographers to design and complete a dictionary project within a relatively short time frame. The result was that, in order to fulfil the needs of translators and text writers, the lexicographers designed and made a syntagmatic specialized dictionary, i.e. a dictionary listing words and terms with definitions and inflectional paradigms, collocations, phrases as well as example sentences. The lexicographers also included various types of speech: nouns (single and multiword units), adjectives, adverbs, prepositions, abbreviations, and verbs, including phrasal verbs. According to Lindemann (2000: 195), this distinguishes the accounting dictionary from existing ones covering the same field with only few collocations, phrases, sentences, and linguistic structures.

The three significant features of the dictionary must be realized as an online accounting dictionary proper. Many regard an electronic dictionary as a database that users access from an interface whose sole function is to give direct access to the dictionary. In other words, the database is identical with the dictionary. However, the Accounting Dictionaries can best be described as an electronic construction with three main components. Firstly, there is a database containing specially selected data that have been structured in a way that facilitates search and retrieval. Secondly, users will see an Accounting Dictionary in the form of a website that does not contain the lexicographical data as these are contained in the database and not in the user interface. Thirdly, in order to provide access to the lexicographical data, a search engine is introduced as an intermediary between the dictionary (user interface) and the database. This search engine allows users to search for data in the database and from there it retrieves the relevant data and presents the results of searches on the screen. In other words, the database is not identical with the dictionary. 
The three-component structure has a number of practical and theoretical implications. Firstly, the database can be the source of several dictionaries as the search engine allows users to make structured searches in structured data through a specific set of online dictionaries. Secondly, the Accounting Dictionaries contain no macrostructures in the traditional text-linguistic sense of the word: a lexicographical structure that arranges lemmata in a specific order so that they can easily be found, as defined in e.g. Hausmann and Wiegand (1989: 336). The Accounting Dictionaries allow users to access data in the database and present the search results on the computer screen in a structured way, no matter where the data were actually located in the database. The macrostructure has been replaced by a data presentation structure that arranges the data retrieved from the database according to type, and presents these data in a predetermined order depending on user needs as identified by the type of help sought; see Nielsen and Almind (2011: 147-151) for a detailed discussion of the database.

The adoption of the functional theory of lexicography combined with the three-component electronic platform resulted in an extension of the project. It was now possible to have a large bilingual database in which a search engine could search for data in two languages and retrieve selected types of data irrespective of language. The lexicographers decided to produce a Danish-English accounting dictionary as well as a Danish accounting dictionary. One reason for this was that the Danish data types supporting the function translation from Danish into English could be used in a separate Danish accounting dictionary. The Danish definitions, inflectional paradigms, collocations, phrases, example sentences, cross-references and external links support communicative functions such as providing help to understand Danish accounting texts and to write accounting texts in Danish, as well as the cognitive functions of providing help to acquire knowledge about Danish accounting matters and accounting language. This strengthens the claim made earlier that the lexicographical database is not identical with the dictionary: one database and two dictionaries.

The two accounting dictionaries were made available to the public in 2003. They each contained about 4,200 headwords, or lemmas, about 15,400 collocations and phrases, and about 1,000 example sentences, providing users with guidance concerning correct language as well as subject-matter information. Being Internet dictionaries, the Danish accounting dictionary and the DanishEnglish accounting dictionary benefit from the advantage of open-ended electronic dictionaries: space. As accounting language develops rapidly in the modern world of financial regulation and crises, space is important, and the database allows lexicographers to add, revise and delete data, thereby enlarging the dictionaries on an ongoing basis (see Nielsen and Mourier 2007). In 2004, Regnskabsordbogen dansk-engelsk (Danish-English Accounting Dictionary) was published in print based on selected data found in the database and used for the Danish-English online accounting dictionary (Nielsen, Mourier and Bergenholtz 2004). 
The success with the two completed dictionaries led the lexicographers to design an English accounting dictionary and an English-Danish accounting dictionary. The theoretical basis as described above was retained in an adapted form and a new bilingual database was created partly based on the data from the first one. Work progressed along the same lines as before and the result was two online accounting dictionaries that provided help to specific types of users to solve specific types of problems when translating accounting texts from English into Danish, producing accounting texts directly in English, reading English accounting texts, and acquiring knowledge about English accounting matters and accounting language. The two new accounting dictionaries were made available on the Internet by end-2004, each containing about 6,000 headwords, about 20,000 collocations and phrases, and about 2,000 example sentences. In 2007, Regnskabsordbogen engelsk-dansk (English-Danish Accounting Dictionary) was published in print based on selected data found in the database and used for the English-Danish online accounting dictionary (Nielsen, Mourier and Bergenholtz 2007).

The change from linguistic to functional principles described so far illustrates important aspects of the development in lexicography in general and specialized lexicography in particular. A dictionary is seen as an information tool with three significant features that, combined with the theory of lexicographical functions, allow lexicographers to complete dictionary projects quickly. Moreover, the electronic platform with three components makes it possible to compile a database that can be used to make several electronic and printed dictionaries.

\section{The inclusion of Spanish}

In October 2008, a group of Spanish lexicographers, translators and accounting experts started the translation of the English lexicographical data stored in the accounting database. At that time, the database contained around 6,000 English dictionary articles, which were translated into or adapted to Spanish accounting in around 11 months (see Bergenholtz 2012, Fuertes-Olivera and Nielsen 2012, and Fuertes-Olivera and Tarp 2014 for a description of the data categories included in this database). The Spanish team worked as follows:

- The chief Spanish lexicographer explained the definition of the English lemma to the accounting experts. For around 95\% of the English terms, the explanations given allowed the accounting experts to identify the corresponding Spanish equivalents.

- The chief Spanish lexicographer attached Spanish grammar and inflections to the Spanish equivalents.

- $\quad$ Two translators of English specialized texts translated the collocations and example sentences that contextualize each English headword (around 20,000 English collocations and 2,000 English example sentences). 
- $\quad$ The chief Spanish lexicographer and the accounting experts included translations and/or adaptations of English synonyms and antonyms (where necessary). They also included contrastive notes, where necessary, and internal and external cross-references, i.e. links to other dictionary articles or to external web-pages, typically the homepage of the Instituto de Contabilidad y Auditoría de Cuentas, which is the official institution in charge of accounting standards, rules, and procedures in Spain.

- The chief Spanish lexicographer and the accounting experts coined the Spanish equivalents of the English terms that had not been identified in step 1 above; sometimes, this coinage consisted in accepting equivalents found in other dictionaries or in Internet homepages, or verbatim translations of English accounting lemmas (Fuertes-Olivera 2011).

- A Spanish native speaker trained in Spanish grammar and a Danish Professor of Spanish who teaches specialized translation proofread all the Spanish data present in the editors' layout "English-Spanish" of the accounting database (Figure 1). Their role was to check errors, mistakes, etc.

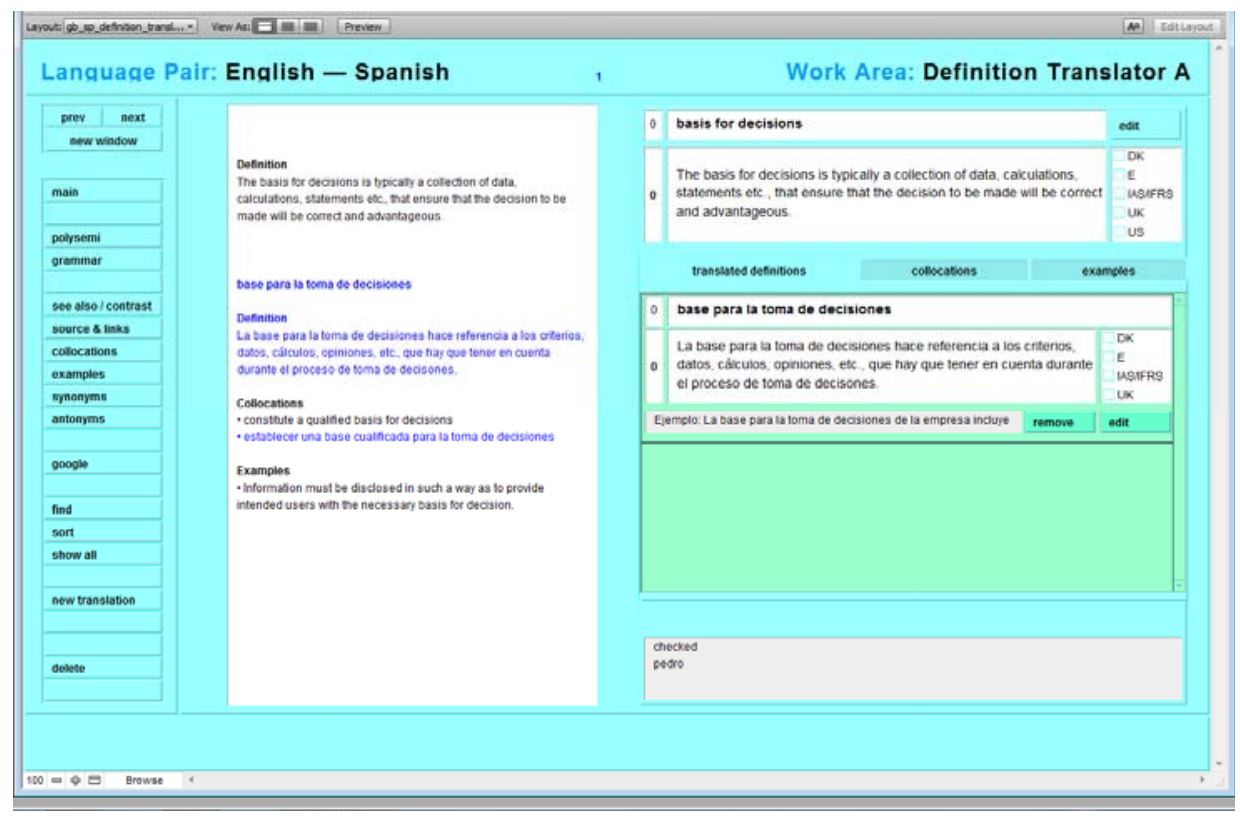

Figure 1: Screenshot of the English-Spanish accounting database (editors' layout: Definition)

By December 2009, IT experts based in the Centre for Lexicography, Aarhus University, converted the data into a polyfunctional online dictionary (Nielsen 
et al. 2009), and a printed one (Fuertes-Olivera et al. 2010). There are some differences between them: for example, the printed dictionary does not contain external cross-references, i.e. links to web-pages. Examples 1 and 2 show the dictionary entry for Consumer Price Index in the online and printed dictionaries respectively: the grammar data and inflectional paradigms are only found in the online dictionary; the online dictionary does not use symbols but words, i.e. it uses "synonyms" instead of the sign "=":

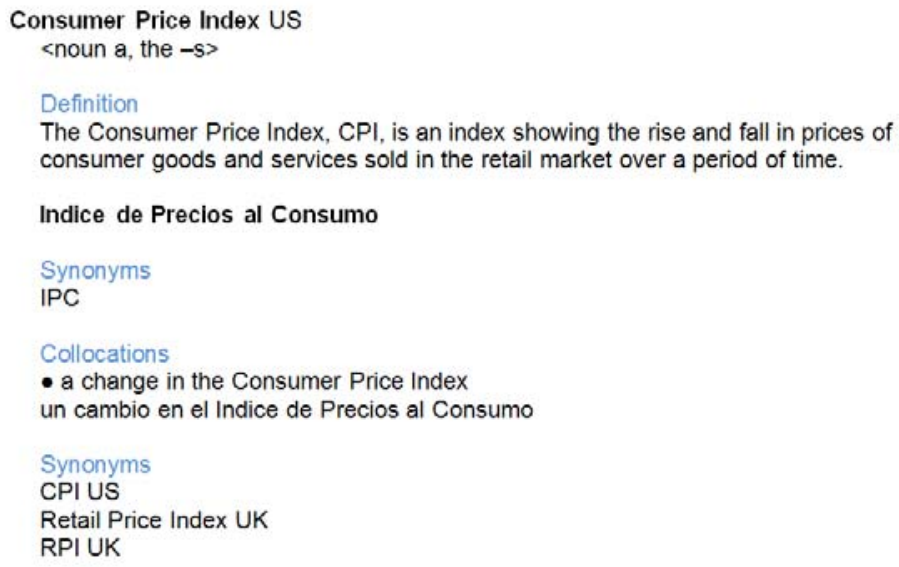

Example 1: Consumer Price Index in the online dictionary (Nielsen et al. 2009)

\author{
Consumer Price Index uS \\ = CPI Us, Retail Price Index \\ UK, RPI UK \\ The Consumer Price Index, \\ CPI, is an index showing the \\ rise and fall in prices of consu- \\ mer goods and services sold in \\ the retail market over a period \\ of time. \\ Indice de Precios al Consumo \\ $=\mathrm{IPC}$ \\ A a change in the Consumer Pri- \\ ce Index un cambio en el Indice \\ de Precios al Consumo
}

Example 2: Consumer Price Index in the printed dictionary (Fuertes-Olivera et al. 2010)

The IT experts also prepared a new database for storing Spanish accounting data, e.g. the Spanish lemmas, their Spanish definitions, grammar, inflections, external and internal links, contrastive data, collocations, and example sentences. 
This database is modeled as the English and Danish one, as shown in Figure 2:

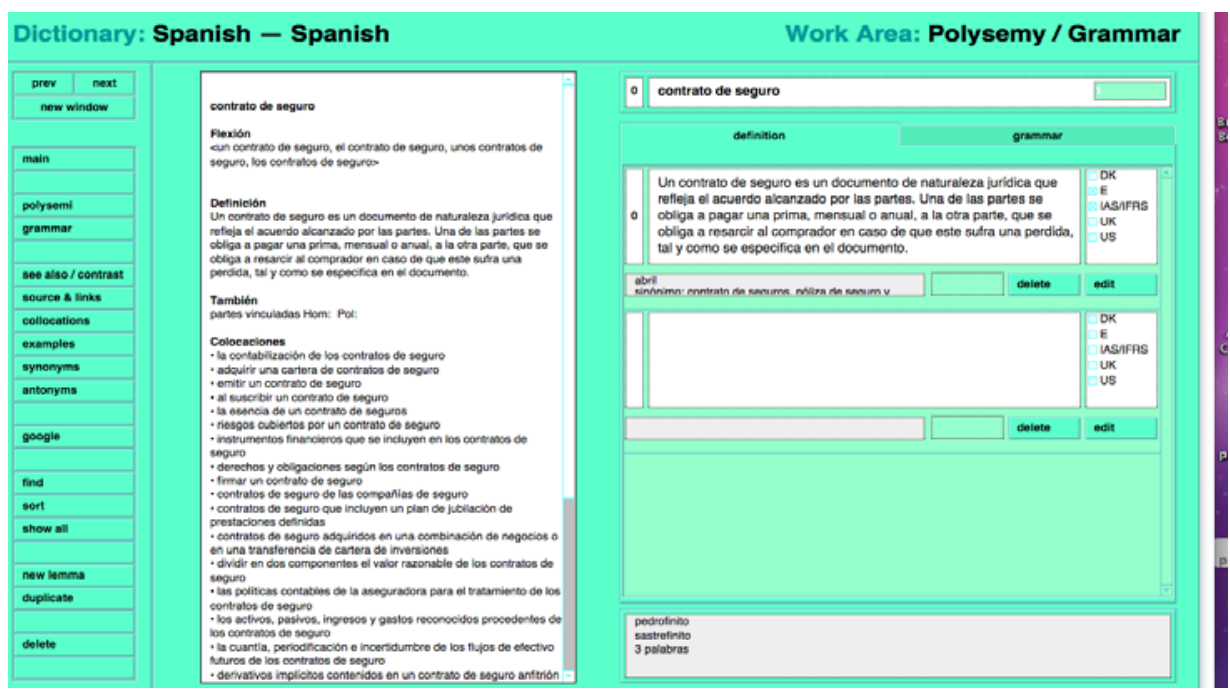

Figure 2: Screenshot of the Spanish accounting database (editors' layout: Polysemy and Grammar)

This new editors' layout was available in October 2011. At that time, the team initiated the storage of data as described below:

- $\quad$ The chief Spanish lexicographer and the accounting experts selected the Spanish lemmas, firstly from the Spanish equivalents included in the English-Spanish accounting dictionary, then from several accounting texts, and finally from an in-house corpus (see Fuertes-Olivera et al. 2013, and Fuertes-Olivera and Tarp 2014 for a description of the process).

- The chief Spanish lexicographer attached grammar and inflections to each Spanish headword.

- The chief Spanish lexicographer and the accounting experts crafted the Spanish definitions and decided on questions concerning homonymy and polysemy; this definition could be a translation or an adaptation of the English definition. It could also be new or containing cultural information connected with Spanish accounting rules and traditions (FuertesOlivera and Tarp 2014).

- The rest of the Spanish team completed the dictionary articles, e.g. collocations, example sentences, synonyms, usage and contrastive notes. All the data included were taken from accounting texts, most of which were downloaded from the Internet (see Fuertes-Olivera and Tarp 2014 for a description of the process). 
By the end of 2012, the storage system contained around 6,500 Spanish dictionary articles. At that time, lexicographers and experts started working in a new layout of the accounting database, prepared by IT experts in Aarhus for including Spanish-English accounting data (Figure 3). At the time of writing this article, around 4,000 dictionary articles have been completed and it is expected that more than 6,000 dictionary articles will be completed by the end of 2013.

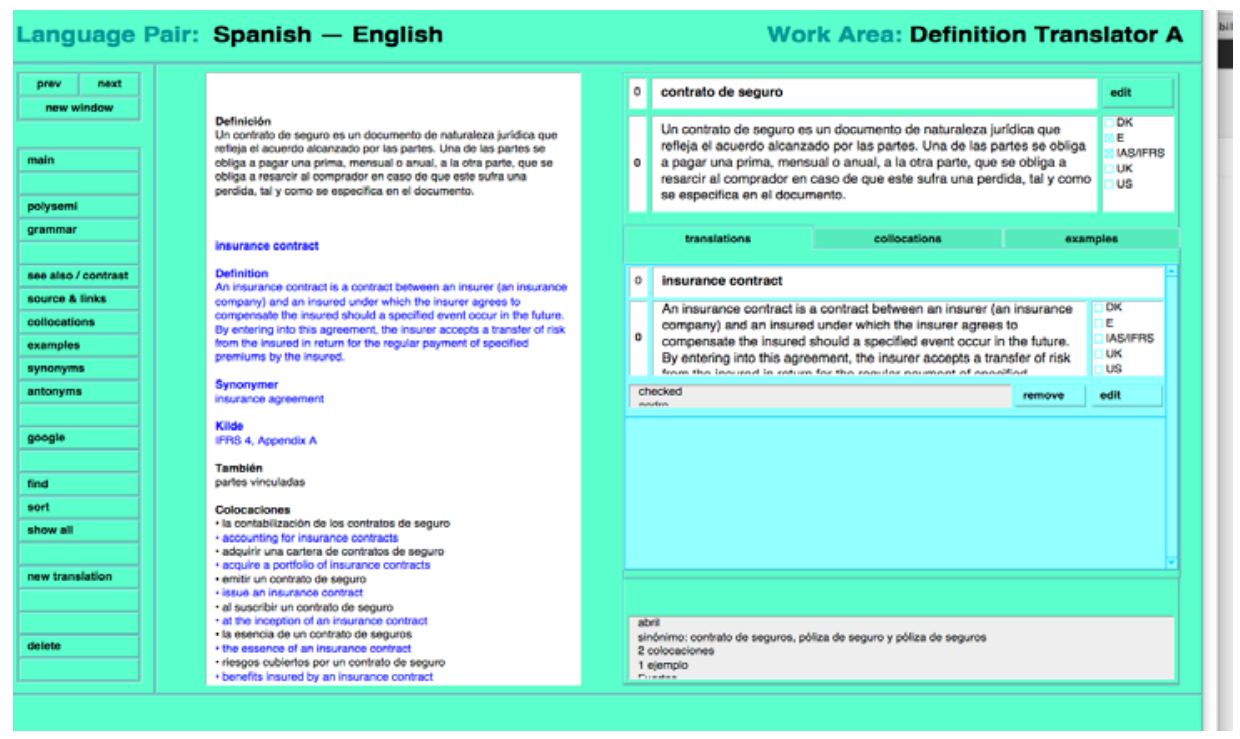

Figure 3: Screenshot of the Spanish-English accounting database (editors' layout: Definition)

As explained below, proponents of the function theory of lexicography are always open to include innovations, assuming that these agree with the conception of user needs in specific extra-lexicographical situations (Nielsen 2009a; and Tarp 2008). This intellectual situation resulted in replacing the polyfunctional dictionaries with innovative monofunctional dictionaries (Bergenholtz 2011, 2012), initially described as Model T Ford dictionaries, i.e. dictionaries whose articles and visualized lexicographical data are adapted to the various functions displayed by the dictionary, frequently assisted by different types of interactive options where users may define themselves and the activity for which they need information (Tarp 2011; and Fuertes-Olivera and Tarp 2014). In other words, the originally conceived and published polyfunctional accounting dictionaries are under a process of constant updating and conversion into monofunctional online dictionaries. 


\section{Conversion of the polyfunctional English and Danish dictionaries into usage-based monofunctional ones}

The original polyfunctional nature of the dictionaries affected access to and presentation of data. When they searched for words, users would be presented with full articles resembling those in printed dictionaries with data types intended to support a plurality of usage situations. This meant that users had to read, or at least skim, entire articles to find the answers they were looking for because the text contained relatively little relevant data among a large collection of data. As a result the lexicographical information costs for users were higher than necessary (see Nielsen 2008 for a detailed discussion of information costs in lexicography). This is a common problem with general and specialized dictionaries, printed as well as electronic, that want to cater to everyone in every type of usage situation. However, various developments allow lexicographers to design dictionaries so that users can easily access the data and process these into useful information.

The ease with which users will be able to acquire the necessary information from the data in dictionaries can be examined in terms of lexicographical information costs. These costs may be defined as the efforts that users believe or feel are associated with consulting a dictionary, an article or any other text part of a dictionary. Search-related information costs are the efforts related to the look-up activities users have to perform when consulting a dictionary in order to access the relevant data, while comprehension-related information costs are the efforts related to users' ability to understand the data presented in a dictionary (Nielsen 2008: 173-174). The problem with polyfunctional dictionaries is that it may require relatively much effort to search for the answer users need in an article containing several data types of which most are irrelevant for a specific search. On top of that, it may require much effort to decode the meaning of the data in order to find the specific data that answer your question, because they will have to be interpreted in the light of the rest of the data to make sure that you have found the lexicographical help needed. In other words, lexicographical Model T Fords should be able to reduce search- and comprehension-related information costs by making access to and interpretation of data easy and quick.

The technological development of online resources can be combined with the development in the function theory of lexicography. By focusing on the needs of users in various types of usage situations, lexicographers can select electronic solutions that ensure retrieval of data that satisfy a specific type of need and can present the data in such a way that users can easily turn them into useful information. From end-2009 to mid-2011 the lexicographers at the Centre for Lexicography developed one single database that replaced the previous ones and now allows the lexicographers to use advanced electronic options. One result was that the polyfunctional monolingual and bilingual accounting dictionaries were substituted by monofunctional dictionaries. Per- 
sons who find themselves in a particular type of communicative or cognitive usage situation may need help of a specific kind and consult the accounting dictionary most likely to provide assistance. Users can consult one of four Danish and four English accounting dictionaries for the following kinds of help:

- Meaning of accounting term (usage situation: I am reading an accounting text and want help to understand an accounting term)

- Use of known accounting term (usage situation: I am writing an accounting text and want help to produce the text with a known word)

- Use of accounting term whose meaning is known (usage situation: I am writing an accounting text and want help to find and use a term that has a specific meaning)

- Knowledge of accounting matters (usage situation: I want to know more about accounting matters or accounting language)

Users can consult one of four Danish-English and four English-Danish accounting dictionaries for the following kinds of help:

- Meaning of accounting term (usage situation: I am reading an accounting text and want help to understand an accounting term)

- Translation of known accounting term (usage situation: I am translating an accounting text and want help to translate a known word)

- Translation of collocation (usage situation: I am translating an accounting text and want help to translate a collocation)

- Knowledge of accounting matters (usage situation: I want to know more about (comparative) accounting matters or accounting language)

This means that each dictionary has different functions and search options specifically made for each function. There are now eight monolingual and eight bilingual accounting dictionaries with the languages Danish and English, all developed from a single database.

In order to keep information costs as low as possible, the search engine allows users to perform targeted searches in the database. Readers of accounting texts may want to know the meaning of the English accounting term reinsurer and consult the English Accounting Dictionary: Meaning whose function is to provide the meaning of accounting terms. The search engine makes a targeted search for the term and retrieves the definitional data addressed to the term as illustrated in Example 3.

Example 3 shows how the monofunctional dictionary helps users by presenting limited data that are specifically selected to support the communicative function: help users understand the meaning of a particular term. The relevant 
data are easy to find as they are not hidden among other, and for the function irrelevant, data; users only need a definition and nothing more in this type of usage situation.

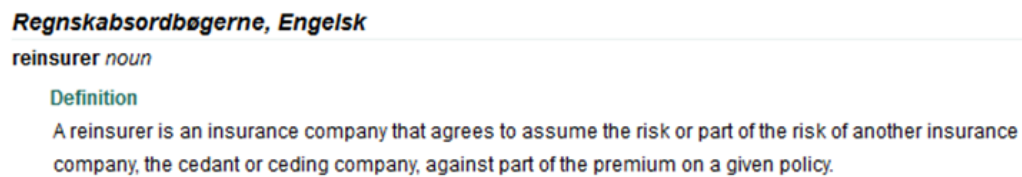

Example 3: Definition helping to understand the accounting term

Authors may want help to write texts in English in which the term reinsurer occurs. The search engine allows users to select the English Accounting Dictionary: Text Production whose function is to show how known accounting terms can be used. The result of the search is shown in Example 4.

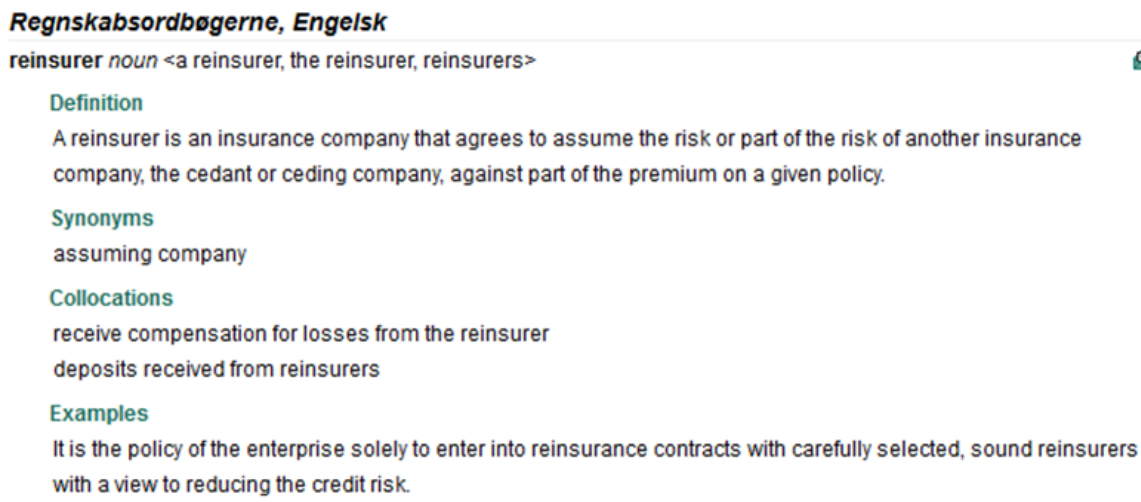

Example 4: Help to write accounting texts where the expression is known

The definition in Example 4 enables users to check that the term found has the correct meaning, and the grammar data, synonyms, collocations and example sentences support the writing process. The writing process generally concerns terminology, phraseology, grammar, syntax, and pragmatics, hence the data types presented in the monofunctional accounting dictionary whose communicative function is to help users write accounting texts. In particular, writers prepare drafts, check the texts to ensure that generally acceptable grammar and spelling rules are complied with, that the appropriate terminology has been used consistently so that the texts are unambiguous, and that the texts are free from errors; see Nielsen (2006) for a discussion of monolingual accounting dictionaries for text production.

The English Accounting Dictionary: Knowledge provides help in cognitive usage situations. People may want to acquire general or specific knowledge 
about the accounting concept reinsurer and the search engine retrieves and presents the data in a predetermined order illustrated in Example 5.

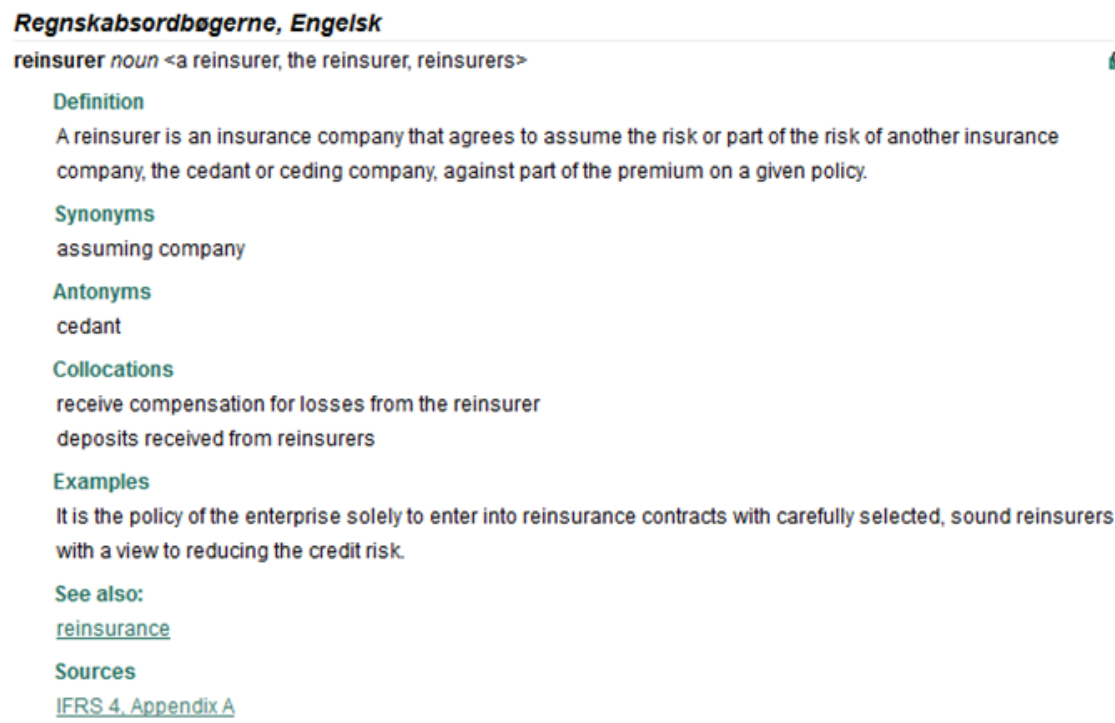

Example 5: Help to acquire knowledge in cognitive usage situations

In Example 5, the definition explains the meaning of the term, which is supplemented by an example sentence. Synonyms and antonyms help users put the term reinsurer in its terminological hierarchy within the domain. In addition, users can click the underlined cross-reference (under See also) containing an embedded link and come to another article with relevant additional data; the item indicating the source of the definition also has an embedded link users can click to go to the website of the international financial reporting standard (IFRS) for more information.

Danes who translate accounting texts may have problems translating the English term reinsurer. They can find assistance in the English-Danish Accounting Dictionary: Translation whose function is to provide help to translate accounting terms, and Example 6 shows the search result for reinsurer.

In addition to presenting the meaning of the term in Example 6, the dictionary presents the recommended Danish equivalent: reassurandør. The alternative Danish term genforsikringsselskab is presented as a synonym. English collocations and example sentences with their translations into Danish as well as the inflectional paradigm help users to translate accounting texts in which the search term occurs.

Examples 3 to 6 are examples of how the monofunctional accounting dictionaries covering the languages Danish and English work. Each example shows that the monofunctional approach keeps information costs low as the 
dictionaries in each case only present data supporting communicative and cognitive functions respectively. In contrast, polyfunctional dictionaries would likely have presented all the data shown in Example 5 in all cases and left it to users to find the relevant data that could help them. Finally, it should be noted that searches are conducted in and results retrieved from one single database.

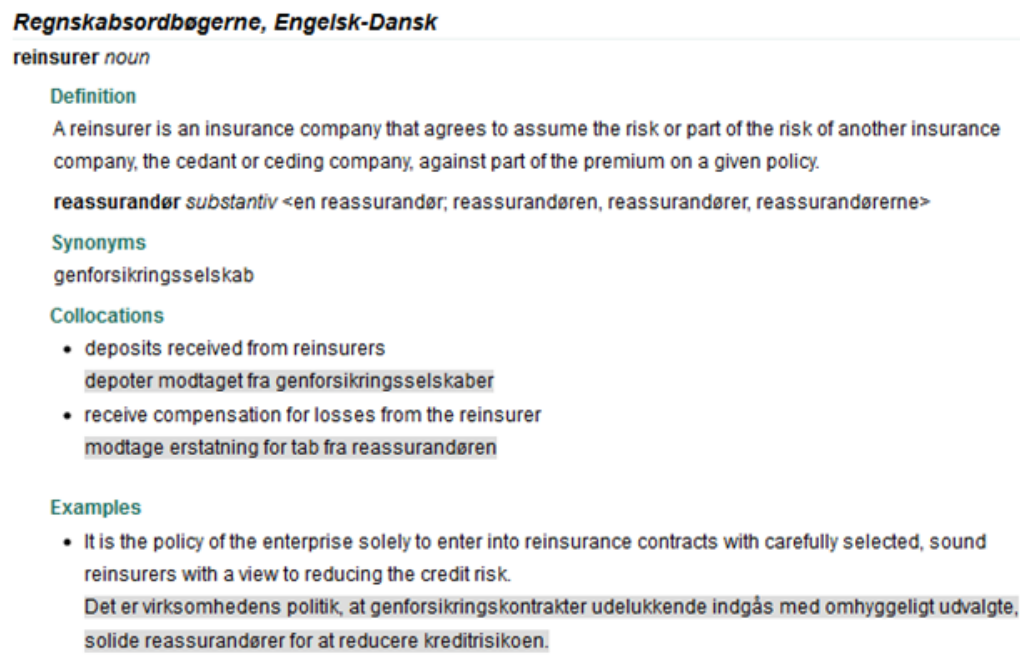

Example 6: Data providing help to translate an accounting term

\section{Conversion of the polyfunctional English and Spanish dictionaries into usage-based monofunctional ones}

The conversion of the polyfunctional English and Spanish dictionaries into usage-based English and Spanish dictionaries followed the theoretical principles described in section 4 above. This process rested on the idea that lexicographical databases and dictionaries are different things. This has allowed the dictionary team to convert the originally conceived polyfunctional dictionaries into twelve accounting dictionaries, eight of which are already in operation: there are four English-Spanish accounting dictionaries and four Spanish accounting dictionaries that offer the same kind of help discussed in Section 4.

In addition, users of the English-Spanish and Spanish dictionary sets have two more innovations. One of them is that the English-Spanish accounting set contains English and Spanish definitions of the English lemmas. The Spanish definitions are included for two main reasons. The first is that some targeted users (Spanish students and interested laypeople) are not as proficient in English as their Danish counterparts and the Spanish definitions will help them to understand the accounting concepts (i.e. low information costs). The second reason is that some of the definitions also include cultural data, e.g. data for 
explaining that building societies are English institutions that are different from Spanish sociedades constructoras (Eng.: building firms or construction companies); they are similar to Spanish co-operatives or mutual savings banks, two organizations that are easily identified in Spain and that have a similar function to the building society described in the dictionary article (Example 7).

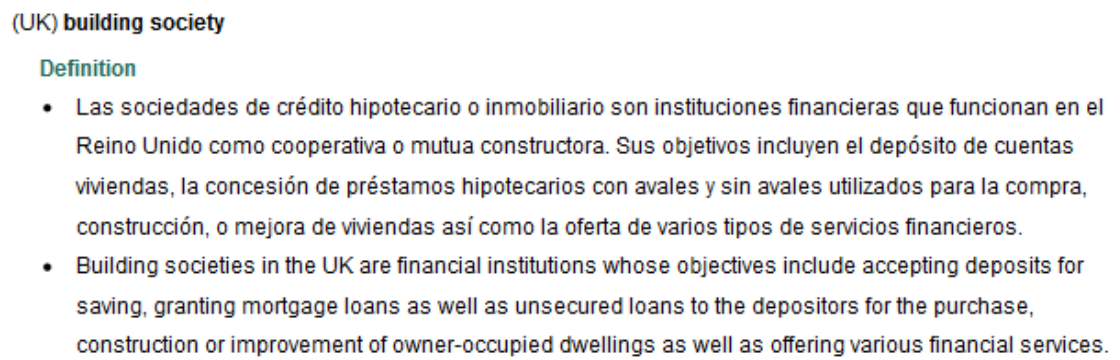

Example 7: Definitions of building society in the English-Spanish accounting dictionary: Meaning

The second innovation is the inclusion of the search engine "encontrar un termino" (Eng.: find a term) that allows searching with a term, part of it and three Boolean operators: "+", "-", and "or". For instance, a search for +contabilidad +año retrieves some terms (e.g. contabilidad creativa) and verb forms (contabilizando), which can be clicked (Example 8). A search for +contabilidad OR año retrieves different terms (e.g. contabilidad de caja) and some of its inflections (la contabilidad de caja and una contabilidad de caja) (Example 9). A search for +contabilidad OR retrieves several possible terms and inflections (Example 10). In other words, this search option offers users possible ways of finding a term they do not remember (perhaps, they only have the gist of the concept and need several searches before finding what they are looking for).

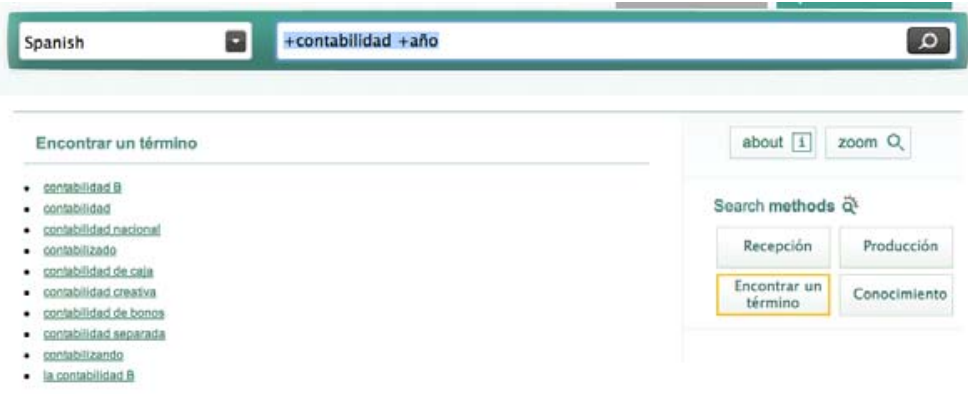

Example 8: Data providing help for finding an unknown accounting term 


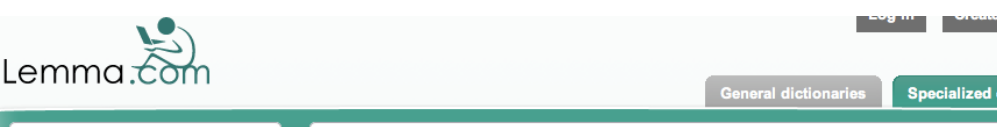

Spanish $\quad$ +contabilidad OR año

\begin{tabular}{|c|c|c|}
\hline Encontrar un término & about 1 & zoom \\
\hline $\begin{array}{l}\text { - contabililad de caja } \\
\text { - contabilildad de bonos }\end{array}$ & \multicolumn{2}{|c|}{ Search methods $a^{k}$} \\
\hline - la contabilidad de cala & Recepción & Pr \\
\hline - contabilidad creativa & $\begin{array}{l}\text { Encontrar un } \\
\text { término }\end{array}$ & Cor \\
\hline
\end{tabular}

- contabilidad separada

- contabilidad externa

contabilidad interna

Example 9: Data providing help for finding an unknown accounting term

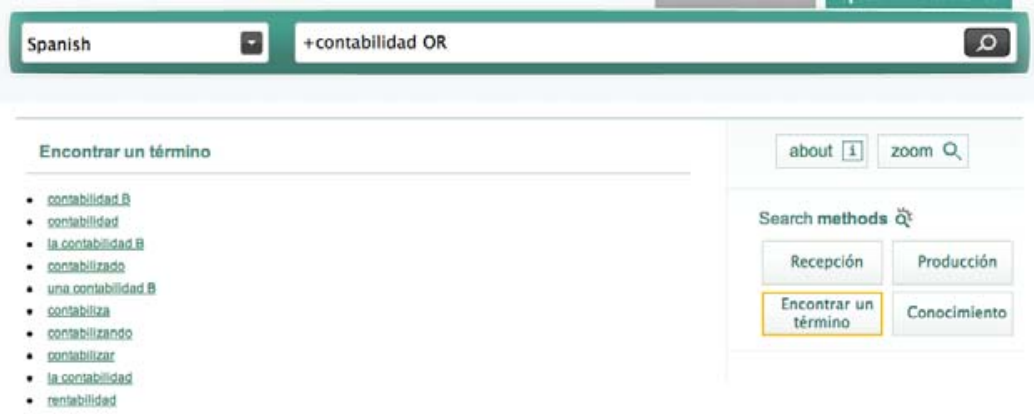

Example 10: Data providing help for finding an unknown accounting term

\section{Conclusion and implication for the future}

This article places the true nature of lexicography within the tenets of the Function Theory of Lexicography, i.e. the theoretical construction initiated in the Centre for Lexicography at the Aarhus School of Business (Bergenholtz and Tarp 2002, 2003, 2004; also Tarp 2008, and Fuertes-Olivera and Tarp 2014). It indicates that lexicography in general and specialized lexicography in particular deals with more than language and facts. It also keeps up with and adapts to the developments of a modern information society. For instance, the advent of the Internet allows lexicographers to move from constructing printed polyfunctional dictionaries to designing sets of electronic monofunctional ones. One example of this change is the conversion of the originally polyfunctional accounting dictionary into 28 monofunctional dictionaries, 24 of which are already in operation and can be consulted at Ordbogen.com or Lemma.com. 
This article has traced the history of the lexicographical project since its inception in 2001. At that time, lexicographers at the Centre for Lexicography intended to construct a tool to help Danish enterprises meet the increasing need to present their financial reporting in linguistically and terminologically correct English. A few years later, the objectives of the project were enlarged, a new language - Spanish - was included, and new ideas and technologies came into operation, e.g. the distinction between the lexicographical database, the search engine, and the homepage. These new concepts integrated well within the general framework espoused in the function theory of lexicography: dictionaries are tools and are designed for satisfying specific types of needs in specific types of extra-lexicographical usage situations.

The making of the project also has implications for the future: this dictionary project is a typical product of the knowledge-based economy we have been constructing so far. Lexicographers work in the cloud being physically thousands of kilometres away; they work with experts in accounting, databases and the Internet with the aim of constructing and updating high-quality tools with low information costs, i.e. tools that are sold on a subscription basis. It may be envisaged that the future of lexicography is illustrated by the working of this project: It is based on sound research and is constantly transforming with the aim of producing sellable, innovative and useful lexicographical products. In other words, it is likely that the future of lexicography rests on designing, constructing, and updating information tools that take into consideration not only the true nature of lexicography but also the possibilities of the Internet and its technologies. This article has shown how this can be done within the general framework of the Function Theory of Lexicography.

\section{Acknowledgments}

Thanks are due to the Ministerio de Economía y Competitividad and to the Junta de Castilla y León for financial support (Grant FF12011-22885 and VA 067A12-1 respectively).

\section{References}

\section{Accounting Dictionaries}

Fuertes-Olivera, P.A., H. Bergenholtz, S. Nielsen, P. Gordo Gómez, L. Mourier, M. Niño Amo, Á. de los Ríos Rodicio, Á. Sastre Ruano, S. Tarp and M. Velasco Sacristán. 2012. Diccionario Inglés-Español de Contabilidad: Conocimiento. Base de Datos y Diseño: R. Almind and J. Skovgård Nielsen. Odense: Lemma.com.

Fuertes-Olivera, P.A., H. Bergenholtz, S. Nielsen, P. Gordo Gómez, L. Mourier, M. Niño Amo, Á. de los Ríos Rodicio, Á. Sastre Ruano, S. Tarp and M. Velasco Sacristán. 2012. Diccionario Inglés-Español de Contabilidad: Recepción. Base de Datos y Diseño: R. Almind and J. Skovgård Nielsen. Odense: Lemma.com. 
Fuertes-Olivera, P.A., H. Bergenholtz, S. Nielsen, P. Gordo Gómez, L. Mourier, M. Niño Amo, Á. de los Ríos Rodicio, Á. Sastre Ruano, S. Tarp and M. Velasco Sacristán. 2012. Diccionario Inglés-Español de Contabilidad: Traducción. Base de Datos y Diseño: R. Almind and J. Skovgård Nielsen. Odense: Lemma.com.

Fuertes-Olivera, P.A., H. Bergenholtz, S. Nielsen, P. Gordo Gómez, L. Mourier, M. Niño Amo, Á. de los Ríos Rodicio, Á. Sastre Ruano, S. Tarp and M. Velasco Sacristán. 2012. Diccionario Inglés-Español de Contabilidad: Traducción de Frases y Expresiones. Base de Datos y Diseño: R. Almind and J. Skovgård Nielsen. Odense: Lemma.com.

Fuertes-Olivera, P.A., H. Bergenholtz, S. Nielsen, P. Gordo Gómez, M. Niño Amo, Á. de los Ríos Rodicio, Á. Sastre Ruano, S. Tarp and M. Velasco Sacristán. 2013. Diccionario Español de Contabilidad. Conocimiento. Base de Datos y Diseño: R. Almind and J. Skovgård Nielsen. Hamburg: Lemma.com.

Fuertes-Olivera, P.A., H. Bergenholtz, S. Nielsen, P. Gordo Gómez, M. Niño Amo, Á. de los Ríos Rodicio, Á. Sastre Ruano, S. Tarp and M. Velasco Sacristán. 2013. Diccionario Español de Contabilidad: Encontrar un Término. Base de Datos y Diseño: R. Almind and J. Skovgård Nielsen. Hamburg: Lemma.com.

Fuertes-Olivera, P.A., H. Bergenholtz, S. Nielsen, P. Gordo Gómez, M. Niño Amo, Á. de los Ríos Rodicio, Á. Sastre Ruano, S. Tarp and M. Velasco Sacristán. 2013. Diccionario Español de Contabilidad: Producción. Base de Datos y Diseño: R. Almind and J. Skovgård Nielsen. Hamburg: Lemma.com.

Fuertes-Olivera, P.A., H. Bergenholtz, S. Nielsen, P. Gordo Gómez, M. Niño Amo, Á. de los Ríos Rodicio, Á. Sastre Ruano, S. Tarp and M. Velasco Sacristán. 2013. Diccionario Español de Contabilidad: Recepción. Base de Datos y Diseño: R. Almind and J. Skovgård Nielsen. Hamburg: Lemma.com.

Fuertes-Olivera, P.A., P. Gordo Gómez, M. Niño Amo, Á. de los Rios Rodicio, Á. Sastre Ruano, S. Tarp, M. Velasco Sacristán, S. Nielsen, L. Mourier and H. Bergenholtz. 2010. Diccionario de Contabilidad Inglés-Español. Navarra: Thomson Reuters-Aranzadi.

Nielsen, S., L. Mourier and H. Bergenholtz. 2003-2009. Den Dansk-Engelske Regnskabsordbog. Aarhus: Centre for Lexicography. Available at: http//www.ordbogen.com.

Nielsen, S., L. Mourier and H. Bergenholtz. 2003-2009. Den Danske Regnskabsordbog. Aarhus: Centre for Lexicography. Available at: http//www.ordbogen.com.

Nielsen, S., L. Mourier and H. Bergenholtz. 2004. Regnskabsordbogen dansk-engelsk. Copenhagen: Thomson.

Nielsen, S., L. Mourier and H. Bergenholtz. 2004-2009. Den Engelsk-Danske Regnskabsordbog. Aarhus: Centre for Lexicography. Available at: http//www.ordbogen.com.

Nielsen, S., L. Mourier and H. Bergenholtz. 2004-2009. Den Engelske Regnskabsordbog. Aarhus: Centre for Lexicography. Available at: http//www.ordbogen.com.

Nielsen, S., L. Mourier and H. Bergenholtz. 2007. Regnskabsordbogen engelsk-dansk. Copenhagen: Thomson.

Nielsen, S., L. Mourier and H. Bergenholtz. 2012. Den Dansk-Engelske Regnskabsordbog: Betydning. Odense: Ordbogen.com. Available at: http//www.ordbogen.com.

Nielsen, S., L. Mourier and H. Bergenholtz. 2012. Den Dansk-Engelske Regnskabsordbog: Oversættelse. Odense: Ordbogen.com. Available at: http//www.ordbogen.com.

Nielsen, S., L. Mourier and H. Bergenholtz. 2012. Den Dansk-Engelske Regnskabsordbog: Oversættelse af ordforbindelse. Odense: Ordbogen.com. Available at: http//www.ordbogen.com. 
Nielsen, S., L. Mourier and H. Bergenholtz. 2012. Den Dansk-Engelske Regnskabsordbog: Viden. Odense: Ordbogen.com. Available at: http//www.ordbogen.com.

Nielsen, S., L. Mourier and H. Bergenholtz. 2012. Den Danske Regnskabsordbog: Betydning. Odense: Ordbogen.com. Available at: http//www.ordbogen.com.

Nielsen, S., L. Mourier and H. Bergenholtz. 2012. Den Danske Regnskabsordbog: Hvad hedder dette regnskabsudtryk? Odense: Ordbogen.com. Available at: http//www.ordbogen.com.

Nielsen, S., L. Mourier and H. Bergenholtz. 2012. Den Danske Regnskabsordbog: Tekstproduktion. Odense: Ordbogen.com. Available at: http//www.ordbogen.com.

Nielsen, S., L. Mourier and H. Bergenholtz. 2012. Den Danske Regnskabsordbog: Viden. Odense: Ordbogen.com. Available at: http//www.ordbogen.com.

Nielsen, S., L. Mourier and H. Bergenholtz. 2012. Den Engelsk-Danske Regnskabsordbog: Betydning. Odense: Ordbogen.com. Available at: http//www.ordbogen.com.

Nielsen, S., L. Mourier and H. Bergenholtz. 2012. Den Engelsk-Danske Regnskabsordbog: Oversættelse. Odense: Ordbogen.com. Available at: http//www.ordbogen.com.

Nielsen, S., L. Mourier and H. Bergenholtz. 2012. Den Engelsk-Danske Regnskabsordbog: Oversættelse af ordforbindelser. Odense: Ordbogen.com. Available at: http://www.ordbogen.com.

Nielsen, S., L. Mourier and H. Bergenholtz. 2012. Den Engelsk-Danske Regnskabsordbog: Viden. Odense: Ordbogen.com. Available at: http//www.ordbogen.com.

Nielsen, S., L. Mourier and H. Bergenholtz. 2012. Den Engelske Regnskabsordbog: Betydning. Odense: Ordbogen.com. Available at: http//www.ordbogen.com.

Nielsen, S., L. Mourier and H. Bergenholtz. 2012. Den Engelske Regnskabsordbog: Hvad hedder dette regnskabsudtryk? Odense: Ordbogen.com. Available at: http//www.ordbogen.com.

Nielsen, S., L. Mourier and H. Bergenholtz. 2012. Den Engelske Regnskabsordbog: Tekstproduktion. Odense: Ordbogen.com. Available at: http//www.ordbogen.com.

Nielsen, S., L. Mourier and H. Bergenholtz. 2012. Den Engelske Regnskabsordbog: Viden. Odense: Ordbogen.com. Available at: http//www.ordbogen.com.

Nielsen, S. L. Mourier, H. Bergenholtz, P.A. Fuertes-Olivera, P. Gordo Gómez, M. Niño Amo, A. de los Rios Rodicio, A. Sastre Ruano, S. Tarp and M. Velasco Sacristán. 2009. El Diccionario Inglés-Español de Contabilidad. Available at: http://www.accountingdictionary.dk/regn/gbsp/ regngbsp_index.php.

\section{Other literature}

Audi, R. 2003. Epistemology. A Contemporary Introduction to the Theory of Knowledge. New York/London: Routledge.

Bell, R.T. 2000. Translation and Translating. Theory and Practice. Eleventh printing. London/New York: Longman.

Bergenholtz, H. 1996. Grundfragen der Fachlexikographie. Gellerstam, M., J. Järborg, S.-G. Malmgren, K. Norén, L. Rogström and C.R. Papmehl (Eds.). 1996. Euralex '96 Proceedings I-II, Papers Submitted to the Seventh EURALEX International Congress on Lexicography in Göteborg, Sweden: 731-758. Göteborg: Department of Swedish, Göteborg University.

Bergenholtz, H. 2011. Access to and Presentation of Needs-adapted Data in Monofunctional Internet Dictionaries. Fuertes-Olivera, P.A. and H. Bergenholtz (Eds.). 2011: 30-53.

Bergenholtz, H. 2012. Concepts for Monofunctional Accounting Dictionaries. Terminology 18(2): 243-263. 
Bergenholtz, H. and U. Kaufmann. 1997. Terminography and Lexicography. A Critical Survey of Dictionaries from a Single Specialised Field. Tarp, S. (Ed.). 1997. Specialised Lexicography and Terminology. Hermes 18: 91-125.

Bergenholtz, H. and S. Tarp (Eds.). 1995. Manual of Specialised Lexicography. The Preparation of Specialised Dictionaries. Amsterdam/Philadelphia: John Benjamins.

Bergenholtz, H. and S. Tarp. 2002. Die moderne lexikographische Funktionslehre. Diskussionsbeitrag zu neuen und alten Paradigmen, die Wörterbücher als Gebrauchsgegenstände verstehen. Lexicographica. International Annual for Lexicography 18: 253-263.

Bergenholtz, H. and S. Tarp. 2003. Two Opposing Theories: On H.E. Wiegand's Recent Discovery of Lexicographic Functions. Hermes, Journal of Linguistics 31: 171-196.

Bergenholtz, H. and S. Tarp. 2004. The Concept of "Dictionary Usage". Dollerup, Cai (Ed.). 2004. Worlds of Words. A Tribute to Arne Zettersten. Nordic Journal of English Studies 3(1): 23-36.

Chesterton, G.K. 2001. The Scandal of Father Brown. Kelly Bray: House of Stratus.

Duvå, G. and A.L. Laursen. 1994. Translation and LSP Lexicography: A User Survey. Schaeder, B. and H. Bergenholtz (Eds.). 1994. Fachlexikographie: Fachwissen und seine Repräsentation in Wörterbüchern: 247-267. Tübingen: Gunther Narr.

Frawley, W. 1988. New Forms of Specialized Dictionaries. International Journal of Lexicography 1(3): 189-213.

Fuertes-Olivera, P.A. 2009. Systematic Introductions in Specialised Dictionaries: Some Proposals in Relation to Accounting Dictionaries. Nielsen, S. and S. Tarp (Eds.). 2009: 161-178.

Fuertes-Olivera, P.A. 2011. Equivalent Selection in Specialized e-Lexicography: A Case Study with Spanish Accounting Terms. Lexikos 21: 95-119.

Fuertes-Olivera, P.A. 2013. E-lexicography: The Continuing Challenge of Applying New Technology to Dictionary Making. Jackson, H. (Ed.). 2013. The Bloomsbury Companion to Lexicography. London: Bloomsbury Publishing.

Fuertes-Olivera, P.A. and H. Bergenholtz (Eds.). 2011. e-Lexicography: The Internet, Digital Initiatives and Lexicography. London/New York: Continuum.

Fuertes-Olivera, P.A., H. Bergenholtz, P. Gordo Gómez, S. Nielsen, M. Niño Amo, Á. de los Rios Rodicio, Á. Sastre Ruano, and M. Velasco Sacristán. 2013. The Construction of Online Specialized Dictionaries: Theory and Practice. Fachsprache. International Journal of Specialized Communication 35: 24-41.

Fuertes-Olivera, P.A. and S. Nielsen. 2012. Online Dictionaries for Assisting Translators of LSP Texts: The Accounting Dictionaries. International Journal of Lexicography 25(2): 191-215.

Fuertes-Olivera, P.A. and S. Tarp. 2014. Theory and Practice of Specialised Online Dictionaries. Lexicography versus Terminography. Berlin/New York: De Gruyter.

Hartmann, R.R.K. and G. James. 2001. Dictionary of Lexicography. London/New York: Routledge.

Hausmann, F.J. and H.E. Wiegand. 1989. Component Parts and Structures of General Monolingual Dictionaries: A Survey. Hausmann, F.J., O. Reichmann, H.E. Wiegand and L. Zgusta (Eds.). 1989. Wörterbücher. Ein internationales Handbuch zur Lexikographie/Dictionaries. An International Encyclopedia of Lexicography/Dictionnaires. Encyclopédie internationale de lexicographie. Volume 1: 328-360. Berlin/New York: Walter de Gruyter.

Landau, S.I. 2001. Dictionaries. The Art and Craft of Lexicography. Second Edition. Cambridge/New York: Cambridge University Press.

Lindemann, M. 2000. Vorüberlegungen zur einem französisch-deutschen Wörterbuch der Fachsprache der Wirtschaft. Wiegand, H.E. (Ed.). 2000. Germanistische Linguistik 151-152: 173-214. 
Hildesheim/New York: Georg Olms.

Muráth, J. 2002. Zweisprachige Fachlexikographie. Budapest: Nemzeti Tanköyvkiadó.

Nielsen, S. 1994. The Bilingual LSP Dictionary. Principles and Practice for Legal language. Tübingen: Gunter Narr.

Nielsen, S. 2002. Lexicographical Basis for an Electronic Bilingual Accounting Dictionary: Theoretical Considerations. http://www.sprog.asb.dk/sn/lexicographicalbasis.htm [accessed 31 July 2013].

Nielsen, S. 2003. Changes in Dictionary Subject Matter. Wiegand, H.E. (Ed.). 2003. Untersuchungen zur kommerziellen Lexikographie der deutschen Gegenwartssprache I. Duden. Das grosse Wörterbuch der deutschen Sprache in zehn Bänden: 109-115. Tübingen: Max Niemeyer.

Nielsen, S. 2006. Monolingual Accounting Dictionaries for EFL Text Production. Ibérica 12: 43-64.

Nielsen, S. 2008. The Effect of Lexicographical Information Costs on Dictionary Making and Use. Lexikos 18: 170-189.

Nielsen, S. 2009a. Reviewing Printed and Electronic Dictionaries. A Theoretical and Practical Framework. Nielsen, S. and S. Tarp (Eds.). 2009: 23-41.

Nielsen, S. 2009b. The Evaluation of the Outside Matter in Dictionary Reviews. Lexikos 19: 207-224.

Nielsen, S. 2010. Specialised Translation Dictionaries for Learners. Fuertes-Olivera, P.A. (Ed.). 2010. Specialised Dictionaries for Learners: 69-82. Berlin/New York: Walter de Gruyter.

Nielsen, S. 2013. The Future of Dictionaries, Dictionaries of the Future. Jackson, H. (Ed.). 2013. The Bloomsbury Companion to Lexicography. London: Bloomsbury Publishing.

Nielsen, S. and R. Almind. 2011. From Data to Dictionary. Fuertes-Olivera, P.A. and H. Bergenholtz (Eds.). 2011: 141-167.

Nielsen, S. and L. Mourier. 2005. Internet Accounting Dictionaries: Present Solutions and Future Possibilities. Hermes, Journal of Linguistics 34: 83-116.

Nielsen, S. and L. Mourier. 2007. Design of a Function-based Internet Accounting Dictionary. Gottlieb, H. and J.E. Mogensen (Eds.). 2007. Dictionary Visions, Research and Practice: Selected Papers From the 12th International Symposium on Lexicography, Copenhagen, 2004: 119-135. Terminology and Lexicography Research and Practice 10. Amsterdam/Philadelphia: John Benjamins.

Nielsen, S. and S. Tarp (Eds.). 2009. Lexicography in the 21st Century. In Honour of Henning Bergenholtz. Amsterdam/Philadelphia: John Benjamins.

Nord, C. 2005. Text Analysis in Translation. Theory, Methodology, and Didactic Application of a Model for Translation-oriented Text Analysis. Amsterdam/New York: Rodopi.

Schaeder, B. and H. Bergenholtz (Eds.). 1994. Fachlexikographie. Fachwissen und seine Repräsentation in Wörterbüchern. Forum für Fachsprachen-Forschung 23. Tübingen: Gunter Narr.

Schneider, F. 1998. Studien zur kontextuellen Fachlexikographie. Das deutsch-französische Wörterbuch der Rechnungslegung. Lexicographica Series Maior 83. Tübingen: Max Niemeyer.

Tarp, S. 2000. Theoretical Challenges to Practical Specialised Lexicography. Lexikos 10: 189-208.

Tarp, S. 2001. The Pedagogical Dimension of the Well-conceived Specialised Dictionary. Ibérica 10: 7-22.

Tarp, S. 2008. Lexicography in the Borderland between Knowledge and Non-knowledge. General Lexicographical Theory with Particular Focus on Learner's Lexicography. Tübingen: Max Niemeyer.

Tarp, S. 2009. Reflections on Lexicographical User Research. Lexikos 19: 275-296.

Tarp, S. 2011. Lexicographical and Other e-Tools for Consultation Purposes: Towards the Individualization of Needs Satisfaction. Fuertes-Olivera, P.A. and H. Bergenholtz (Eds.). 2011: 54-70.

Van Sterkenburg, P.G.J. (Ed.). 2003. A Practical Guide to Lexicography. Terminology and Lexicog- 
raphy Research and Practice 6. Amsterdam/Philadelpia: John Benjamins.

Wang, W. 2001. Zweisprachige Fachlexikographie. Benutzungsforschung, Typologie und mikrostrukturelle Konzeption. Angewandte Sprachwissenschaft 8. Frankfurt am Main [etc.]: Peter Lang.

Wiegand, H.E. 1988. Was eigentlich ist Fachlexikographie? Mit Hinweisen zum Verhältnis von sprachligem und enzyklopädischem Wissen. Munske, H.H., P. von Polenz, O. Reichmann and R. Hildebrandt (Eds.). 1988. Deutscher Wortschatz. Lexikologische Studien. Ludwig Erich Schmitt zum 80. Geburtstag von seinen Marburger Schülern: 371-409. Berlin/New York: Walter de Gruyter. 